\title{
Outbreak of Egg Drop Syndrome in Bangladesh
}

\author{
Jahangir Alam (Corresponding author) \\ Animal Health Research Division \\ Bangladesh Livestock Research Institute, Savar, Dhaka, 1341. Bangladesh \\ E-mail: alamjahan2003@yahoo.com \\ Md. Al-Mamun \\ Animal Health Research Division \\ Bangladesh Livestock Research Institute, Savar, Dhaka, 1341. Bangladesh \\ E-mail: almamun_blri@yahoo.com \\ Mohammed Abdus Samad \\ Animal Health Research Division \\ Bangladesh Livestock Research Institute, Savar, Dhaka, 1341. Bangladesh \\ E-mail: samad_blri@yahoo.co.nz \\ Mohammed Rahamat Ullah \\ Nestle Bangladesh Limited, Sreepur, Gazipur, Bangladesh \\ E-mail: rahamat.ullah@bd.nestle.com \\ Md. Giasuddin \\ Animal Health Research Division \\ Bangladesh Livestock Research Institute, Savar, Dhaka, 1341. Bangladesh \\ E-mail: mgias04@yahoo.com
}

\author{
M. J. F. A. Taimur \\ Animal Health Research Division \\ Bangladesh Livestock Research Institute \\ Savar, Dhaka,1341. Bangladesh
}

\begin{abstract}
An incident alike to egg-drop syndrome (EDS) occurred in commercial egg laying chickens in Gazipur district, Bangladesh from July to November 2005. The chickens showed decreased egg production along with production of shell less and soft shelled eggs when they were at predicted peak production age. Nutritional status, especially crude protein (16.65-18.50\%) and calcium (2.15-3.62\%) content of the supplied feed was within the range. Virological and serological investigations on causes of decreased egg production and production of soft-shelled and shell less egg by the laying hens revealed that the responsible causative agent is EDS virus. Total seven EDS viruses were isolated from cloacal swab (4), soft-shelled eggs (2) and feces (1). The isolation rate $71.43 \%$ (5/7) was higher in second passage than in first passage $28.57 \%$ (2/7) in duck embryos. None of the 7 viruses grew in chicken embryo even after second passage. All five flocks tested, were vaccinated against infectious bronchitis and Newcastle disease along with other common
\end{abstract}


vaccines generally used in Bangladesh but not against EDS. Serological investigation revealed that birds in all tested farms $(100 \%$ ) had antibody against EDS virus (in 2 farms in $100 \%$ samples and in 3 farms in $80 \%$ samples). The source of the virus remained to be determined. To the best of our knowledge, this is the first report of EDS outbreak in Bangladesh. To save poultry industry in Bangladesh from harm of this disease the biosecurity measures should be strictly followed along with vaccination against the disease.

Keywords: Soft shell egg, Reduced egg production, Laying chicken, Bangladesh

\section{Introduction}

A syndrome causing lower egg production associated with the laying of soft-shelled and shell less egg was first described in the Netherlands in 1976 and reported that the possible causative agent of the syndrome was fowl adenovirus (Van Eck et al., 1976). Later, several haemagglutinating adenoviruses were isolated by McFerran et al., (1978) from affected hens in Northern Ireland and the correlation between the syndrome and the isolate was demonstrated (McFerrin et al., 1977; McCraken et al., 1978). The disease now called egg drop syndrome (EDS) caused by EDS virus is the foremost cause of loss of egg production in laying hens throughout the world. The most common feature of the disease is production of shell less or thin-shelled eggs by apparently healthy birds. The disease is cosmopolitan in distribution and virus was isolated from France, Great Britain, Belgium, Israel, Australia, Japan, Hungary, Singapore, Taiwan, South Africa, India and China, (Picault, 1978; Baxendale, 1978; Meulemans et al., 1979; Malkinson, \& Weisman, 1980; Firth et al., 1981; Yamaguchi et al., 1981; Zsak et al., 1981; Singh \& Chew-Lim, 1981; Lu, et al., 1985b; Bragg, et al., 1991; Kumar et al., 1992; Zhu \& Wang, 1994). Antibody to the virus was demonstrated from chickens of Denmark, Brazil, Mexico, Nigeria and New Zealand (Badstue \& Smidt, 1978; Hwang et al., 1980; Rosales et al., 1980; Nawathe et al., 1980; Howell, 1982).

In the last two decades the poultry industry has grown from a handful of medium sized operations to a large industry in Bangladesh. Poultry farms having sizes ranging from a few hundred birds to several hundred thousand birds are mushrooming throughout the country. Side by side small-scale family poultry system (backyard poultry) is also one of the most important income-generating source for rural women, landless poor and marginal farmers. In 1997-98 the small-scale family poultry system in Bangladesh has been estimated to account for about $80 \%$ of the total poultry population (Huque, 1999).

Different infectious and non-infectious diseases have been affecting both native and high performing commercial poultry across the country (Giasuddin et al., 2002) round the year. From July to November 2005, many farmers from Gazipur district reported that their birds have been laying shell less and soft-shelled eggs along with dropped egg production. Farm owners supplied extraneous vitamins like vit. $\mathrm{AD}_{3} \mathrm{E}, \mathrm{B}$ complex and minerals viz. calcium phosphorus preparation, oyster shell, dicalcium phosphate etc. to chickens but hens did not get improvement. Present report deals with the virological and serological investigation of the etiologic agent (s) responsible for the aforesaid problems.

\section{Materials and Methods}

\subsection{Farmer's interview and sample collection}

Farmer's interview was taken using a set of preformed questioner. Information regarding age, breed, population, origin or source of chick, age of occurrence of dilemma, duration of occurrence, feed used to fed, affect on bird or on egg production, measures already taken (medication and extra feed ingredients supplementation), vaccination and recovery status, etc. were collected. During investigation the following infectious diseases viz. Newcastle disease (ND), infectious bronchitis (IB), egg drop syndrome (EDS) and noninfectious cases viz. nutritional deficiency were considered and indispensable information and samples were collected. A total of five farms from four villages under Sadar upazilla of Gazipur district were visited to collect information and samples. After collection the samples were soon transferred to Poultry Disease Diagnosis Laboratory, Bangladesh Livestock Research Institute (BLRI), Savar, Dhaka, Bangladesh, about $30 \mathrm{~km}$ far from sampling area, maintaining appropriate measures. A total of 90 different samples from 5 different farms were collected that includes cloacal swab ( $\mathrm{n}=25,5$ samples from each farm), environmental sample that is feces from floor $(\mathrm{n}=25,5$ samples from each farm), thin-shelled eggs $(\mathrm{n}=10,2$ samples from each farm), blood ( $\mathrm{n}=25,5$ samples from each farm), and feed $(\mathrm{n}=5,1$ samples from each farm). Collected samples were processed and tested for above-mentioned infectious and non-infectious cases. Feed samples were used for analysis of crude protein $(\mathrm{CP})$ and calcium $(\mathrm{Ca})$ content. Serological tests were done with sera separated from blood samples. Cloacal swabs, feces and egg samples were processed and used for virus isolation and identification.

\subsection{Inocula preparation and embryo inoculation}

Soon after collection cloacal swabs were put in to a tube having $1.0 \mathrm{ml}$ of transport buffer which contains penicillin 100 units $/ \mathrm{ml}$, streptomycin $100 \mu \mathrm{g} / \mathrm{ml}$, gentamycin $50 \mu \mathrm{g} / \mathrm{ml}$, amphotericin B $0.5 \mu \mathrm{g} / \mathrm{ml}$ in phosphate buffered saline (PBS $\mathrm{pH}$ 7.2) and stored at $4^{\circ} \mathrm{C}$ overnight to facilitate antimicrobial activity. After vortex the samples were centrifuged in refrigerated centrifuge machine at $10,000 \mathrm{~g}$ for 5 minutes and supernatant was collected and used as inoculum. On the 
other hand $25 \%$ suspension of feces and egg samples were made with antibiotic solution in PBS and the inocula were prepared as mentioned above.

Specific pathogen free eggs (SPF) were obtained from a research farm of BLRI. All the virological samples were inoculated in SPF embryonated chicken and duck eggs (White Leg Horn incase of chicken and Khaki Campbell incase of duck) through allantoic cavity route for Newcastle disease virus (NDV) and EDS virus and chorioallantoic membrane route for infectious bronchitis virus (IBV) according to the method described (Alexander, 2003; McFerrin et al., 2003; Cavanagh \& Naqi, 2003). Age of inoculated embryo was 9-11 days. Each egg was inoculated with $0.2 \mathrm{ml}$ of inoculum and for each inoculum 5 eggs were used. PBS was inoculated in 5 eggs as negative control. The eggs were incubated at $37^{\circ} \mathrm{c}$ for 5 days and checked twice daily for livability. Death of embryos within 24 hours was considered as accidental. The eggs were chilled soon after found dead or upon incubation period.

\subsection{Haemagglutination (HA) test}

The HA test was carried out by the conventional microtiter method using $0.5 \%$ chicken red blood cell (RBC) suspension. The highest dilution showing complete agglutination was taken as the virus titer.

\subsection{Haemagglutination inhibition (HI) Test ( $\alpha$-method)}

To identify and differentiate the haemagglutinating virus/es present in the allantoic fluid, HI test was conducted using NDV and EDS virus specific antisera. Japan International Co-operation Agency (JICA) provides specific antisera of NDV and EDS virus. HI test was conducted by the conventional microtiter method (alpha method) for virus (antigen) detection. Briefly, two fold serial dilution of $25 \mu \mathrm{l}$ HA positive allantoic fluid was made with PBS in U bottom microtiter plate (Nunc). Pretitrated $25 \mu \mathrm{l}$ antiserum/well either for NDV or EDS virus was added and allowed to stand at room temperature for 60 minutes to facilitate antigen antibody reaction. About $50 \mu 1$ of $0.5 \%$ chicken red blood cell (RBC) suspension was added into each well and again allowed to stand at room temperature for 40 minutes. The result was observed without any aids.

\subsection{Antibody Titration}

Serum was separated from collected blood samples. To clarify, the serum was centrifuged at $800 \mathrm{xg}$ for 10 minutes and used in serological tests. HI test was employed for NDV antibody detection whereas enzyme linked immunosrobant assay (ELISA) was performed for IBV and EDS virus antibody titration.

\subsubsection{Haemagglutination inhibition (HI) Test ( $\beta$-method)}

The test was done as described in the chapter on Newcastle Disease in the world Organization for Animal Health (OIE) Manual for Diagnostic Tests and Vaccines for Terrestrial Animals, Chapter 2.1.15 [http://www.oie.int/eng/normes/mmanual/A_00038.htm entered on 4 June 2008] using 4 haemagglutinating units of antigen. Highest dilution of serum causing complete inhibition of 4 HA unit of antigen is considered as HI titer of the serum. The validity of results was assessed against a negative and a positive control serum along with back titration of antigen used in $\mathrm{HI}$ test. $\mathrm{HI}$ titer is considered as positive if there is inhibition at a serum dilution of $1 / 8\left(2^{3} \operatorname{or}^{\log _{2} 3}\right.$ when expressed as the reciprocal).

\subsubsection{Enzyme linked immunosorbant assay (ELISA)}

ELISA kits (FlockChek Infectious Bronchitis Virus Antibody Test Kit, IDEXX, USA) and BioCheck Egg Drop Syndrome Antibody Test Kit, BioCheck B. V. Holland) were obtained and ELISA procedures were followed (manufacturer instruction). ELISA plate was read using an ELISA plate reader (BIORAD-550, California, USA).

\subsection{Feed analysis}

Feed analysis was done by Poultry feed analysis laboratory of BLRI following standard protocol.

\section{Results}

\subsection{Outbreak information, egg production loss and feed analysis}

Since July 2005, egg laying chickens started to lay abnormal shaped, thin-shelled, and shell less eggs along with lower egg production in many layer farms of Gazipur district in Bangladesh. The chickens were quiet healthy apparently and showed no other clinical symptoms. The feed consumption, water intake, plumage color, comb, etc were normal. The authors visited five farms of four villages of Sadar Upazila of Gazipur district and gathered information and relevant clinical samples for laboratory analysis. Information collected through interview is presented in Table 1. All 5 farmers rear chicken in the cage and have been facing this problem for last 2-3 weeks. Soon after start of laying shell less, soft-shelled, misshapen eggs, the farmers applied i) medicine like Gentamycin, Oxytetracycline (Renamycin, Bactitab) and other sulfur drugs ii) feed ingredients like, calcium-phosphorus premixes, oyster shell, dicalcium phosphate (DCP), calcium carbonate, soybean oil and iii) Vitamin $\mathrm{B}$ complex and $\mathrm{AD}_{3} \mathrm{E}$ preparation. No effect has been observed either on egg production or in reduces production of shell less and soft-shelled eggs. The egg production reduces 
approximately $30-54 \%$ (Table 2). The $\mathrm{CP}$ and $\mathrm{Ca}$ content of the feed ranges from $16.65-18.50 \%$ (Farm $\mathrm{A}=18.25 \%, \mathrm{~B}=$ $18.50 \%, \mathrm{C}=16.65 \%, \mathrm{D}=18.25 \%$ and $\mathrm{E}=18.25 \%$ ) and $2.15-3.85 \%$ (Farm $\mathrm{A}=2.5 \%, \mathrm{~B}=3.25 \%, \mathrm{C}=2.85 \%, \mathrm{D}=3.62 \%$ and $\mathrm{E}=2.15 \%$ ) respectively. In farm C, CP content was bit lower (16.65\%).

\subsection{Serological findings}

Blood samples were collected from chicken and tested by HI (NDV) and ELISA (IBV and EDS virus) test and the results are depicted in the Table 3 and 4 . Antibody against NDV and IBV was found in all samples $(100 \%)$ tested for all 5 farms (100\%). Whereas antibody against EDS virus was found in $100 \%$ samples of 2 farms and $80 \%$ of 3 farms (4). Titer against NDV ranges from 5-9 Log2 with averages 5.60 $\pm 0.25,6.60 \pm 0.51,6.40 \pm 0.51,6.40 \pm 0.40$ and $8.40 \pm 0.40$ for farm A, B, C, D and E respectively (Table 3). Antibody to IBV is also quiet high for protection. The average titers in chicken of farm A, B, C, D and E are 5193 $\pm 1279,5865 \pm 2356,5369 \pm 1254,4026 \pm 783,4149 \pm 1529$ respectively (Table 4). More or less similar trend was found incase of antibody to EDS virus (Table 4). All chickens had been vaccinated against ND, IB (Table 1) along with other vaccines but not against EDS.

\subsection{Virus isolation and identification}

After five days incubation of inoculated chicken and duck embryos, allantoic fluid was tested by HA test using $0.5 \%$ chicken RBC(Lancaster, 1966; Adair, 1979; Lu et al., 1985a). Seven haemagglutinating viruses were isolated from cloacal swab (4), soft-shelled eggs (2) and feces (1). The viruses grow only in duck embryo (Table 5). Isolation rate is higher in second passage $71.43 \%(5 / 7)$ when compared to $1^{\text {st }}$ passage $28.57 \%(2 / 7)$. None of the seven viruses grew in chicken embryo even after second passages. Haemagglutination inhibition (HI) test with NDV and EDS virus specific antisera was performed to identify the haemagglutinating virus present in the allantoic fluid. Specific antibody against NDV failed to inhibit the haemagglutinating activity of virus present in to allantoic fluid. Whereas EDS virus specific antiserum do it. HI index for ND virus is negligible or poor, ranges from 0-1 but for EDS virus it ranges from 4-8 (Table 5).

\section{Discussion}

In the last two decades the poultry industry has grown from a handful of medium sized operations to a large industry in Bangladesh. Poultry farms having sizes ranging from a few hundred birds to several hundred thousand birds are mushrooming throughout the country. Side by side small-scale family poultry system (backyard poultry) is also one of the most important income-generating source for rural women, landless poor and marginal farmers. In 1997-98 the small-scale family poultry system in Bangladesh has been estimated to account for about $80 \%$ of the total poultry population (Huque, 1999). Different infectious and non-infectious diseases have been affecting both native and high performing commercial poultry across the country round the year (Giasuddin et al., 2002). Data generated by the Department of Livestock Service shows that the loss of livestock due to various diseases resulted in losses of approximately 140000 million taka per year in the mid eighties (Hassan, 1985).

From July to November 2005 many farmers from Gazipur district, one of the biggest poultry zone in Bangladesh, reported that their birds have been laying shell less and soft-shelled eggs along with dropped egg production (Alam et al., 2006). To investigate the cause/s of this problem the authors visited related farms, collected samples along with farmers' interview. Farmers supplemented to the chicken with different antibiotics, vitamin and mineral preparations (Table 1) but hens did not get improvement. Banerjee, (1993) reported that the CP and Ca requirements of layer birds aged between $20-80$ weeks are $18 \%$ and $2.75 \%$ respectively. We found the $\mathrm{CP}(16.65-18.50 \%)$ and $\mathrm{Ca}(2.15-3.85 \%)$ content of the supplied feed was within the optimum range in most of the flocks. Moreover, farmers supplied extra Ca, vitamin and mineral preparation (Table 1) during the course of the problem. This result indicates that the problem was not related to bacteriological infection or nutritional deficiency. The farmers observed no respiratory signs for last three weeks and also the authors did not find any respiratory problem during visit which encouraged initial role out of IB virus infection. One farmer (Farm E) reported that one of his chicken flocks housed in different house showed similar signs and recovered about 45 days later. But now another flock, visited by the authors, started to lay soft-shelled eggs. The owner of farm A reported about chickens of another farm, near to his farm, recovered from same problem after 30 days of suffering. The age of birds which showed the problem ranges from 30-38 weeks, peak production stage, except one flock which was 54 weeks (Table 1). And during the cascade production losses ranges from 30-54\%. These findings have likeness to the findings on EDS reported earlier (Malkinson \& Weisman 1980; Van Eck, 1976). McFerran and Adair, (2003) reported that EDS usually occurs when production remains between 50\% to peak level and lasts in a flock for 4-10 weeks with resultant about 40\% drop in egg production (Table 2). In Japan the disease first broken out in broiler breeder farm and egg production falls when the flocks were 30-55 weeks of age. The cascade continued for 3-7 weeks which leading to $20-25 \%$ drop in egg production (Yamaguchi et al., 1981).

As the chickens were vaccinated against ND and IB (Table 1), it is usual to get antibody against these viruses (Table 3 and Table 4) and the titers are high enough to protect chicken from infection. But antibody in blood against EDS virus (Table 4) creates question from where and how this antibody develop? The possible answer may due to be from field 
exposure to EDS virus which is responsible for current cascade with resultant soft-shelled, shell less eggs or reduced egg production in layer farms. Is it the fact? To answer the question virus isolation and identification was performed.

None of the 7 isolates could not grow in chicken embryos. Moreover, haemagglutination activity was not inhibited by NDV specific antiserum as shown by $\mathrm{HI}$ index (Table 5). These results indicate that the virus present in allantoic fluid is not NDV. On the other hand, all of the isolates grown in duck embryos and EDS virus specific antiserum completely inhibits haemagglutination activity of the virus present in allantoic fluid, showed as HI index (Table 5) indicates that the virus present in the allantoic fluid is EDS virus which does not grows in chicken embryos. Present findings have the similarity with the findings of Alexander, (2003), Cavanagh and Naqi, (2003) and McFerran and Adair (2003) who reported that ND and IB viruses can grow in chicken embryo whereas EDS virus grows in duck embryos but not in chicken embryos. Growth of embryos incase of sample inoculated eggs was compared with PBS inoculated eggs. There was no visual retardation of growth noticed, usually caused by IB virus which indicates there might be no IB virus in the sample.

Serological and virological investigations corroborate that the tested flocks infected with EDS virus and the virus stimulates adaptive immune reaction with resultant seroconversion (Table 4) against EDS virus. Question may arise is it possible to excrete virus when there is antibody against that virus in blood? The answer is yes. Domermuth and Gross (1991) reported that chicken can excrete virus even when they have high antibody titer in the blood level. identified EDS virus from clinical cases with similar signs and symptoms of EDS infection. During our visit we observed marshy land and plenty of trees On the basis of postmortem and serological investigation Giasuddin et al., (2002) reported presence EDS virus in Bangladesh although there was no outbreak of the disease happened nor was virus isolated at that time. Further more, recently Biswas et al (2008) reported sero positive cases of EDS76 virus in local chickens in Bangladesh. In the present study we isolated and alike to forest around farms with wild birds and waterfowls. Moreover, small wild bird has easy access to the farm for food. This may create a route of entry of virus to the farm although the virus can transmit vertically. The authentic sources of virus remained to be determined. Furthermore, study is needed to characterize the virus especially using restriction enzymes along with other phenotypical characteristics.

\section{Conclusion}

Virological and serological investigation on causes of decreased egg production and production of soft-shelled and shell less egg by the laying hens revealed that the responsible causative agent is EDS virus. This is the first report of outbreak of EDS in Bangladesh so far.

\section{Acknowledgement}

The authors are grateful to Japan International Co-operation Agency (JICA) for supplying specific antisera against NDV and EDS virus. Rezia Khatun, Scientific Officer, BLRI is gratefully acknowledged for performing the feed analysis. Special thanks to Dr. Kazuaki Takehara, Kitasato University for innumerable effort to improve the present report.

\section{References}

Adair, B. M., McFerran, J. B., Connor, T. J., McNulty, M. S. \& McKillop, E. R. (1979). Biological and Physical properties of a virus (strain127) associated with egg drop syndrome 1976. Avian Pathology, 8, 249-264.

Alam, J., Al-Mamun, M., Samad, M. A., Rahamat Ullah, M., Giasuddin M. \& Taimur, M. J. F. A. 2006. Shell-less, thin-shelled egg and production drop problem in commercial layer farms of Gazipur.Proceedings of the $12^{\text {th }}$ BSVER Annual Scientific Conference, BAU, Mymensingh, 30-31 January 2006.

Alexander, D. J. (2003). Newcastle disease, Other Avian Paramyxoviruses, and Pneumovirus Infection. In Y.M. Saif, H.J. Barnes, J.R. Gilson, A.M. Fadly, L.R. McDouglad \& D.E. Swayne (Eds.), Diseases of Poultry (pp.63-87). Ames:Iowa State Press.

Badstue, P. B. \& Smidt, B. (1978). Egg drop syndrome 76 in Danish poultry. Nord Veterinary Medicine, 30, 498-505.

Banerjee, G. C. (1993). Poultry. (3rd ed.). New Delhi, Bombay: Oxford and IBH Publishing co. Pvt. Ltd. pp.102.

Baxendale, W. (1978). Egg drop syndrome 76. Veterinary Record, 102, 285-286.

Biswas, P. K., Barua, H., Uddin, G. M. N., Biswas, D., Ahad, A., \& Debnath, N. C. 2008. Serosurvey of five viruses in chickens on smallholdings in Bangladesh. doi:10.1016/j.prevetmed. 2008.06.018.

Bragg, R. R., Allwright, D. M. \& Coetzee, L. (1991). Isolation and identification of adenovirus 127, the causative agent of egg drop syndrome (EDS), from commercial laying hens in South Africa. Onderstepoort Journal of Veterinary Research, 58, 309-310.

Cavanagh, D. \& Naqi, S. A. (2003). Infectious bronchitis. In Y.M. Saif, H.J. Barnes, J.R. Gilson, A.M. Fadly, L.R. McDouglad and D.E. Swayne (Eds.), Diseases of Poultry (pp.101-119). Ames: Iowa State Press. 
Domermuth, C. H. \& Gross, W. B. (1991). Haemorrhagic enteritis and related infections. In B.W. Calnek, H.J. Barnes, C.W. Beard, W.M. Reid \& H.W. Yoder Jr. ( Eds.), Diseases of Poultry (pp.567-572.). Ames: Iowa State University press.

Firth, G. A., Hall, M. J. \&McFerran, J. B. (1981). Isolation of haemagglutinating adeno-like virus related to virus 127 from an Australian poultry flock with an egg drop syndrome. Australian Veterinary Journal, 57, 239-242.

Giasuddin, M., Sil, B. K., Alam, J., Islam, M. R. \& Rahman, M.(2002). Prevalence of poultry diseases in Bangladesh. OnLine Journal of Biological Science, 2, 212-213.

Hassan, A. F. M. R. (1985). Foot and mouth disease in Bangladesh. Paper presented at the World Country Training Programme on Foot and Mouth Disease Control, Bangkok, Thailand.

Howell, J. (1982). Egg drop syndrome in Ross Brown hens:An interim report. Surveillance, 9, 10-11.

Huque, Q.M.E. (1999). Nutritional status of family poultry in Bangladesh. Livestock Rural Development, 11, 3.

Hwang, M. H., Lamas, J. M., Hipolito, O. \& Silva, E. N. (1980). Egg drop syndrome 1976 a serological survey in Brazil. Proceedings of the $6^{\text {th }}$ European Poultry Conference (p.371-378). Hamburg, Germany.

Kumar, R., Mohanty, G. C., Verma, K. C. \& Ram-Kumar. Epizootiological studies on egg drop syndrome in poultry. Indian Journal of Animal Science, 62, 497-501.

Lancaster, J. E. (1966). Newcastle disease, a review 1926-1964. Monograph No. 3. Canadian Department of Agriculture. Ottawa.

Lu, Y. S., Lin, D. F., Tasi, H. J., Lee, Y. L., Chui, S. Y., Lee, C. \& Huang, S. T. (1985a). Outbreaks of egg drop syndromen1976 in Taiwan and isolation of the etiological agent. Journal of Chinese Society of Veterinary Science, 11, 157-165.

Lu, Y. S., Tasi, H. J., Lin, D. F., Chui, S. Y., Lee, Y. L. \& Lee, C. (1985b). Survey of antibody against egg drop syndromen 1976 virus among bird species in Taiwan. Journal of Chinese Society of Veterinary Science, 11, 151-156.

Malkinson, M. \& Weisman, Y. (1980). Serological survey for the prevalence of antibodies to egg drop syndrome 1976 virus in domesticated and wild birds in Israel. Avian Pathology, 9, 421-426.

McCraken, R. M. \& McFerran, J. B. (1978). Experimental reproduction of the egg drop syndrome 1976 with a haemagglutinating adenovirus. Avian Pathology, 7, 483-490.

McFerran, J. B. \& Adair, B. M. (2003). Egg drop syndrome. In Y.M. Saif, H.J. Barnes, J.R. Gilson, A.M. Fadly, L.R. McDouglad and D.E. Swayne (Eds.). Diseases of Poultry (pp. 227-237). Ames:Iowa State Press.

McFerran, J. B., Rowley, H. M., McNulty, M. S. \& Montgomery, L. J. (1977). Serological studies on flock showing depressed egg production. Avian Pathology, 6, 405-413.

McFerran, J. B., McCraken, R. M., McKillop, E. R., McNulty, M. S. \& Collins, D. S. (1978). Studies on a depressed egg production syndrome in Northern Ireland. Avian Pathology, 7, 35-47.

Meulemans, G., Dekegel, D., Peeters, J., Van Meirhaeghe, E. \& Halen, P. (1979). Isolation of an adenolike virus from laying chickens affected by egg drop syndrome 1976. Vlaams Diergeneeskd Tijdschr, 2, 151-157.

Nawathe, D. R. \& Abegunde, A. (1980). Egg drop syndrome 76 in Nigeria: Serological evidence in commercial farms. Veterinary Record, 107: 466-467.

Picault, J. P. (1978). Chutes de ponte associees a la production d'oeufs sans coquille fragile: Proprietes de l'agent infectious isole au cours de la maladie. L'Aviculteur, 379, 57-60.

Rosales, G., Antillon, A. \& Morales, C. (1980). Reporte en Mexico sobre la presencia de anticuerpos contra el adenovirus causante del syndrome de la baja en postura (CEPABC-14) en parvadas de gallinas domesticas. Proceedings of $29^{\text {th }}$ West Poultry Disease Conference. p.192-196.

Singh, K. Y. \& Chew-Lim, M. (1981). Breeder farm egg drop syndrome 1976 (EDS76) in Singapore. Singapore Veterinary Journal, 5, 8-13.

Van Eck, J. H. H., Davelaar, F. G., van Den Heuvel-Plesman, T. A. M., van Kol, N., Kouwenhoven, B. \& Guldie, F. H. M. (1976). Dropped egg production, soft shelled and shell less eggs associated with appearance of precipitins to adenovirus in flocks of laying fowls. Avian Pathology, 5, 261-272.

Yamaguchi, S., Imada, H., Kawamura, H., Taniguchi, T., Saio, H. \& Shimamatsu, K. (1981). Outbreaks of egg drop syndrome 1976 in Japan and its etiological agent. Avian Diseases, 25: 628-641.

Zhu, G. Q. \& Wang, Y. K. (1994). Study on egg drop syndrome 1976 (EDS-76) and its control. Journal of Jiangsu Agricultural Coll., 15, 5-13. 
Zsak, L. \& Kisary, J. (1981). Some biological and physico-chemical properties of egg drop syndrome (EDS) avian adenovirus strainB8/78. Archives of Virology, 68, 211-219.

World Organization of Animal Health (OIE). 2004. Newcastle Disease In: Manual of Diagnostic Tests and Vaccines for Terrestrial Animals. $5^{\text {th }}$ edn. Part 2, Section 2.1, Chapter 2. 1. 15.

Table 1. History of visited farms about genotype, age, feed, medication and vaccination located at different villages of Sadar Upazilla of District Gazipur

\begin{tabular}{|c|c|c|c|c|c|c|}
\hline $\begin{array}{l}\text { Farm and } \\
\text { Address }\end{array}$ & $\begin{array}{l}\text { Breed and } \\
\text { Population }\end{array}$ & $\begin{array}{l}\text { Origin of } \\
\text { chicken }\end{array}$ & $\begin{array}{l}\text { Age } \\
(w k s)\end{array}$ & $\begin{array}{l}\text { Feed } \\
\text { Source }\end{array}$ & Medication & Vaccination \\
\hline $\begin{array}{l}\text { A- Vhurulia } \\
\text { Gazipur }\end{array}$ & $\begin{array}{l}\text { Brown Nick } \\
2000\end{array}$ & $\begin{array}{l}\text { Victor } \\
\text { Breeders }\end{array}$ & 38 & $\begin{array}{l}\text { Paragon } \\
\text { (Ready } \\
\text { feed) }\end{array}$ & $\begin{array}{l}\text { Gentamycin, } \\
\text { Anthelmintics, } \\
\text { Megavit-WS, } \\
\text { Vit.-AD }{ }_{3} \text { E, } \\
\text { Calgophos, Sancal P, } \\
\text { DCP, Methionine, } \\
\text { Oyster shell etc. }\end{array}$ & $\begin{array}{l}\text { IB+ND, } \\
\text { Gumboro, } \\
\text { G+ND, RDV etc. }\end{array}$ \\
\hline $\begin{array}{l}\text { B- Bhanua } \\
\text { Gazipur }\end{array}$ & $\begin{array}{l}\text { Hi Line } \\
500\end{array}$ & $\begin{array}{l}\text { Dhaka } \\
\text { Hatchery }\end{array}$ & 52 & $\begin{array}{l}\text { Mixed } \\
\text { (Hand } \\
\text { made) }\end{array}$ & $\begin{array}{l}\text { CTC, Sancal P, Iocal, } \\
\text { Vit. B+C, Vit. } \mathrm{AD}_{3} \mathrm{E}, \\
\text { Embavit- WS, DCP, } \\
\mathrm{CaCO}_{3}\end{array}$ & $\begin{array}{l}\text { IB+ND, D78, } \\
228 \mathrm{E}, \quad \mathrm{RDV}, \\
\text { Fowl pox etc. }\end{array}$ \\
\hline $\begin{array}{l}\text { C-Bhanua, } \\
\text { Gazipur }\end{array}$ & $\begin{array}{l}\text { Star Cross } \\
1000\end{array}$ & $\begin{array}{l}\text { Paragon } \\
\text { Poultry }\end{array}$ & 36 & $\begin{array}{l}\text { Paragon } \\
\text { (Ready } \\
\text { feed) }\end{array}$ & $\begin{array}{l}\text { Bactitab, Renamycin, } \\
\text { Sulphar drug, } \\
\text { Acimix, } \\
\text { Rena- WS, Megavit- } \\
\text { WS, Livertonic, } \\
\text { Vit. }-\mathrm{AD}_{3} \mathrm{E} \text {, Sancal P } \\
\text { etc. }\end{array}$ & $\begin{array}{l}\text { IB+ND, } 228 \mathrm{E}, \\
\text { Gumboro2, ND } \\
\text { killed etc. }\end{array}$ \\
\hline $\begin{array}{l}\text { D-Torof Para } \\
\text { Gazipur }\end{array}$ & $\begin{array}{l}\text { Shaver } \\
\text { Star Cross } \\
1600\end{array}$ & $\begin{array}{l}\text { Biman } \\
\text { Poultry }\end{array}$ & 34 & $\begin{array}{l}\text { Mixed } \\
\text { (Hand } \\
\text { made) }\end{array}$ & $\begin{array}{l}\text { CTC, Iocal, Calphos, } \\
\text { Vit. - B+C, } \\
\text { Vit. } \mathrm{AD}_{3} \mathrm{E}, \text { Oyster } \\
\text { shell, Phosphocal, } \\
\text { Soybean oil etc. }\end{array}$ & $\begin{array}{l}\text { IB+ND, D78, } \\
\text { 228E, Clone30, } \\
\text { RDV, } \\
\text { Fowl pox etc. }\end{array}$ \\
\hline $\begin{array}{l}\text { E-Harinal, } \\
\text { Gazipur }\end{array}$ & $\begin{array}{l}\text { Lohman } \\
\text { Browm } \\
1200\end{array}$ & $\begin{array}{l}\text { Phenix } \\
\text { Poultry }\end{array}$ & 30 & $\begin{array}{l}\text { Mixed } \\
\text { (Hand } \\
\text { made) }\end{array}$ & $\begin{array}{l}\text { Oyster shell, } \mathrm{DCP} \text {, } \\
\text { Sancal P, Vit. - } \mathrm{AD}_{3} \mathrm{E}\end{array}$ & $\begin{array}{l}\mathrm{IB}+\mathrm{ND}, 228 \mathrm{E}, \\
\text { ND killed etc. }\end{array}$ \\
\hline
\end{tabular}

Megavit-WS: Megavit-water soluble vitamin preparation, DCP: Dicalcium phosphate, CTC: Chlorotetracycline, IB+ND: Infectious bronchitis+ Newcastle disease, G+ND: Gumboro+Newcastle disease, RDV: Ranikhet disease vaccine, D78: Gumboro D78 strain, 228E: Gumboro 228E strain, Clone30: Newcastle disease clone30 strain. 
Table 2. Performance of birds before and during laying of soft shell and shell less eggs along with reduced egg production

\begin{tabular}{lccccccc}
\hline Farm & \multicolumn{3}{c}{ Previous performance } & \multicolumn{3}{c}{ Current performance } & \multirow{2}{*}{$\begin{array}{c}\text { Production } \\
\text { loss (\%) }\end{array}$} \\
\cline { 2 - 6 } & $\begin{array}{c}\text { Age } \\
(\mathrm{wks})\end{array}$ & $\begin{array}{c}\text { Production } \\
(\%)\end{array}$ & $\begin{array}{l}\text { Age } \\
(\text { wks })\end{array}$ & \multicolumn{3}{c}{ Production (\%) } & \\
\cline { 5 - 7 } & & & & Normal & Abnormal & Total & \\
\hline A & $30-35$ & 90 & 38 & 30 & 6 & 36 & 54 \\
B & $28-32$ & 95 & 52 & 54 & 4 & 58 & 37 \\
C & $28-32$ & 96 & 36 & 45 & 6 & 51 & 45 \\
D & $28-32$ & 78.75 & 34 & 34.50 & 6.75 & 41.25 & 37.5 \\
E & 28 & 80 & 30 & 43.75 & 6.25 & 50 & 30 \\
\hline
\end{tabular}

${ }^{a}$ Abnormal egg includes soft-shelled, misshapen, discolored eggs but not included shell less eggs that dropped from the cage and difficult to count.

Table 3. Distribution of haemagglutination inhibition antibody titer against Newcastle disease virus in chickens of different farms sampled ( $\mathrm{n}=25,5$ samples from each farm)

\begin{tabular}{lll}
\hline Farm & \multicolumn{2}{c}{ HI titer $\left(\mathbf{L o g}_{2}\right)$} \\
\cline { 2 - 3 } & \multicolumn{1}{c}{ Individual Titer } & Mean \pm SE \\
\hline A & $6(3), 5(2)$ & $5.60 \pm 0.25$ \\
B & $8(1), 7(2), 6(1), 5(1)$ & $6.60 \pm 0.51$ \\
C & $8(1), 7(1), 6(2), 5(1)$ & $6.40 \pm 0.51$ \\
D & $7(3), 6(1), 5(1)$ & $6.40 \pm 0.40$ \\
E & $9(3), 8(1), 7(1)$ & $8.40 \pm 0.40$ \\
\hline
\end{tabular}

Values in the parenthesis designate number of sample showed that individual titer.

Table 4. Distribution of ELISA antibody titer against infectious bronchitis and egg drop syndrome virus in chickens of different farms sampled ( $\mathrm{n}=25,5$ samples from each farm)

\begin{tabular}{llcl}
\hline Farm & Individual Titer & Mean \pm SE & $\%$ positive \\
\hline i) Antibody titer against infectious bronchitis virus & & \\
A & $3727,7374,5261,8371,1230$ & $5193 \pm 1279$ & 100 \\
B & $3293,3989,5544,1563,14936$ & $5865 \pm 2356$ & 100 \\
C & $10226,5257,3698,4260,3406$ & $5369 \pm 1254$ & 100 \\
D & $3819,2239,2622,4924,6525$ & $4026 \pm 783$ & 100 \\
E & $1688,2264,1805,5344,9646$ & $4149 \pm 1529$ & 100 \\
ii) Antibody titer against egg drop syndrome virus & & \\
A & $3172,965,3473,2579,1130$ & $2264 \pm 517$ & 100 \\
B & $3147,104,3473,1635,3306$ & $2890 \pm 424$ & 80 \\
C & $3275,378,2852,3306,3172$ & $3151 \pm 104$ & 80 \\
D & $3286,3225,3455,3455,3230$ & $3330 \pm 52$ & 100 \\
E & $3473,2463,101,3466,3773$ & $3294 \pm 286$ & 80 \\
\hline
\end{tabular}

Antibody titer below 396 is considered as negative. Negative samples are not included in calculation of mean and standard error. 
Table 5. Isolation and identification of haemagglutinating virus from the samples inoculated in embryos at $5^{\text {th }}$ day post inoculation both at first and second passage in chicken and duck embryos

\begin{tabular}{|c|c|c|c|c|c|c|c|}
\hline \multirow[t]{3}{*}{ Farm } & \multirow[t]{3}{*}{ Sample } & \multicolumn{4}{|c|}{ Haemagglutinating virus titer $(\log 2)$} & \multirow{2}{*}{\multicolumn{2}{|c|}{$\begin{array}{l}\text { HI Index } \\
(\log 2)\end{array}$}} \\
\hline & & \multicolumn{2}{|c|}{ Chicken embryo } & \multicolumn{2}{|c|}{ Duck embryo } & & \\
\hline & & $1^{\text {sta }}$ & $2^{\text {nd } b}$ & $1^{\text {st }}$ & $2^{\text {nd }}$ & NDV & EDSV \\
\hline \multirow[t]{3}{*}{ A } & Cloacal swab & $-{ }^{c}$ & - & - & - & & \\
\hline & Feces & - & - & - & - & & \\
\hline & Egg & - & - & - & $++^{\mathrm{d}}(4)$ & 0 & 4 \\
\hline \multirow[t]{3}{*}{ B } & Cloacal swab & - & - & - & $+(7)$ & 0 & 7 \\
\hline & Feces & - & - & - & - & & \\
\hline & Egg & - & - & - & - & & \\
\hline \multirow[t]{3}{*}{$\mathrm{C}$} & Cloacal swab & - & - & - & $+(6)$ & 0 & 6 \\
\hline & Feces & - & - & - & - & & \\
\hline & Egg & - & - & - & - & & \\
\hline \multirow[t]{3}{*}{$\mathrm{D}$} & Cloacal swab & - & - & $+(4)$ & nd & 0 & 4 \\
\hline & Feces & - & - & - & - & & \\
\hline & Egg & - & - & $+(4)$ & nd & 0 & 4 \\
\hline \multirow[t]{3}{*}{ E } & Cloacal swab & - & - & - & $+(8)$ & 1 & 8 \\
\hline & Feces & - & - & - & $+(7)$ & 0 & 7 \\
\hline & Egg & - & - & - & - & & \\
\hline
\end{tabular}

${ }^{a}$ first passage and ${ }^{b}$ second passage; ${ }^{c}$ negative and ${ }^{d}$ positive for haemagglutinating activity; nd: not done; values in the parenthesis designate virus titer $\left(\log _{2}\right)$; $\mathrm{HI}$ index is calculated as $\mathrm{HA}$ in haemagglutination test minus $\mathrm{HA}$ in Haemagglutination inhibition test (HA - HA in HI). HI index $\geq 3$ is considered as specific inhibition. NDV: Newcastle disease virus, EDSV: Egg drop syndrome virus. 